\title{
A retrospective cohort study on red blood cell morphology changes in pre-school age children under nitrous oxide anesthesia
}

\author{
Ruoxi Wang ${ }^{1}$, Ling Lan ${ }^{1}$, Li Xu' ${ }^{1}$ Bo Zhu ${ }^{1,2^{*}}$ and Yuguang Huang ${ }^{1}$
}

\begin{abstract}
Background: Megaloblastic anemia or bone marrow changes could occur after prolonged nitrous oxide inhalation via vitamin $B_{12}$ inactivation related DNA synthesis impairment. Previous researches have studied hematological changes with nitrous oxide exposure, but only in adults or adolescents. Pre-school age children with active hematopoietic red bone marrow are more vulnerable to potential side effects of nitrous oxide and might experience growth impairment. The purpose of our study was to analyze red blood cell morphology changes under nitrous oxide anesthesia in pre-school age children.

Methods: One hundred thirty-six children under 5 years old scheduled for hemivertebra resection were analyzed. According to fresh gas type in anesthesia records, 71 children who received nitrous oxide in oxygen during anesthesia maintenance were categorized into the nitrous oxide group and the other 65 who received air in oxygen were the air group. Complete blood counts in perioperative period were assessed for anemia, macrocytosis, microcytosis, anisocytosis, hyperchromatosis and hypochromatosis. The peak value and change percentage were calculated for mean corpuscular volume and red cell distribution width.

Results: Forty-two children in the air group (64.6\%) and 30 in the nitrous oxide group (42.3\%) developed anemia $(P=0.009)$. None developed macrocytosis in both groups. Postoperative mean corpuscular volume peaked (mean [95\% confidence interval]) at 83.7(82.9-84.4) fL, and 83.2(82.4-83.9) $\mathrm{fL}$ and postoperative red cell distribution width at 13.8\% (13.4-14.2\%), and 13.9\% (13.6-14.2\%) for the air group and the nitrous oxide group. Both the relative change of mean corpuscular volume $(P=0.810)$ and red cell distribution width $(P=0.456)$ were similar between the two groups.
\end{abstract}

Conclusions: No megaloblastic red blood cell changes were observed with nitrous oxide exposure for $4 \mathrm{~h}$ in preschool age children undergoing hemivertebra resection.

Keywords: Nitrous oxide, Child, preschool, Red blood cells

\footnotetext{
* Correspondence: zhubo@pumch.cn

'Department of Anesthesiology, Peking Union Medical College Hospital, Chinese Academy of Medical Sciences and Peking Union Medical College, Beijing, China

${ }^{2}$ Department of Anesthesiology, Peking Union Medical College Hospital, No.1

Shuaifuyuan, Dongcheng District, Beijing 100730, China
}

(C) The Author(s). 2021 Open Access This article is licensed under a Creative Commons Attribution 4.0 International License, which permits use, sharing, adaptation, distribution and reproduction in any medium or format, as long as you give appropriate credit to the original author(s) and the source, provide a link to the Creative Commons licence, and indicate if changes were made. The images or other third party material in this article are included in the article's Creative Commons licence, unless indicated otherwise in a credit line to the material. If material is not included in the article's Creative Commons licence and your intended use is not permitted by statutory regulation or exceeds the permitted use, you will need to obtain permission directly from the copyright holder. To view a copy of this licence, visit http://creativecommons.org/licenses/by/4.0/ The Creative Commons Public Domain Dedication waiver (http://creativecommons.org/publicdomain/zero/1.0/) applies to the data made available in this article, unless otherwise stated in a credit line to the data. 


\section{Background}

Nitrous oxide $\left(\mathrm{N}_{2} \mathrm{O}\right)$, an inexpensive and odorless gas with low solubility in blood, is widely used for induction and maintenance of anesthesia especially in children and outpatients [1]. Recent studies have shown increased plasma homocysteine concentration in adults [2], adolescents [3] and children [4] under $\mathrm{N}_{2} \mathrm{O}$-based anesthesia, as the result of methionine synthase inhibition via vitamin $B_{12}$ oxidation. Some significant hematologic complications like megaloblastic bone marrow changes have been reported in critically ill patients or those with vitamin $\mathrm{B}_{12}$, folate or methionine synthetic disorders under $\mathrm{N}_{2} \mathrm{O}$ exposure [5]. While in adolescents under major spinal surgery, $\mathrm{N}_{2} \mathrm{O}$ exposure was not associated with megaloblastic anemia [6].

Bone cavities in pre-school age children are filled with active hematopoietic red bone marrow that is vulnerable to vitamin $B_{12}$ and other nutrients deficiency. With increased respiratory rate and shorter drug elimination half-life time, young children are prone to receive larger doses of inhaled anesthetics. Since the side effects of $\mathrm{N}_{2} \mathrm{O}$ are dose-dependent, children undergoing prolonged major surgery are more likely to develop macrocytosis and megaloblastic anemia, which might be accompanied by slower recovery and a longer hospital stay. Scoliosis with hemivertebra is one of the common congenital malformations in young children, and hemivertebra resection, a mature surgery by a specific team of professional surgeons in our hospital [7], is usually performed between 2 to 5 years old. Considering young children might be more vulnerable to $\mathrm{N}_{2} \mathrm{O}$ exposure, a retrospective cohort study on patients under 5 years old scheduled for hemivertebra resection was applied to analyze changes in red blood cell morphology under $\mathrm{N}_{2} \mathrm{O}$ anesthesia.

\section{Methods}

\section{Design and setting}

We retrospectively analyzed changes in red blood cell morphology in pre-school age children under hemivertebra resection. The retrospective cohort study was conducted in Peking Union Medical College Hospital, China, between January 2013 and January 2020, in accordance with the Declaration of Helsinki. Before data collection, the study was approved by the Medical Ethics Committee of Peking Union Medical College Hospital and the registration number was S-K1301. A waiver of informed consent was approved by the institutional review board of Medical Ethics Committee of Peking Union Medical College Hospital because it was a retrospective analysis. We wrote this manuscript according to The Strengthening the Reporting of Observational Studies in Epidemiology (STROBE) checklist.

\section{Study population}

Children under 5 years old, scheduled for hemivertebra resection, with a postoperative hospital stay of more than 3 days and no history of liver or kidney disease were included in this study. This study excluded patients with a history of $\mathrm{N}_{2} \mathrm{O}$ exposure. And for those who underwent more than one such operation, only the first surgery was included. Patients with preoperative hematopoietic disease, and those without complete blood counts (CBCs) before surgery were also excluded.

\section{Anesthesia management}

All patients received standard total intravenous general anesthesia as the clinical routine in our hospital. Some of them received short inhalation anesthesia to open venous access. Propofol $(3 \mathrm{mg} / \mathrm{kg})$, fentanyl $(2 \mu \mathrm{g} / \mathrm{kg})$ and rocuronium $(0.6 \mathrm{mg} / \mathrm{kg})$ were used for induction. General anesthesia was maintained with continuous infusion of propofol and remifentanil. Fentanyl boluses $(1-2 \mu \mathrm{g} / \mathrm{kg})$ were given when needed for intraoperative analgesia. The tidal volume was set at $8-10 \mathrm{~mL} / \mathrm{kg}$ and the respiration rate was set around 20 times per minute with a fresh gas flow of $\mathrm{N}_{2} \mathrm{O} / \mathrm{O}_{2}$ or $\mathrm{Air} / \mathrm{O}_{2} 2 \mathrm{~L} / \mathrm{min}$ at the discretion of the anesthesiologist. Some anesthetists prefer $\mathrm{N}_{2} \mathrm{O}$-based anesthesia for the reduction of other sedative and analgesic drugs. Some were afraid of postoperative nausea and vomiting with $\mathrm{N}_{2} \mathrm{O}$ anesthesia and chose air instead. Intraoperative transcranial motor evoked potential was used during the surgery. Bispectral index score was maintained between 40 and 60 , and the hemodynamic variables were controlled within $20 \%$ of baseline values. Lactated Ringer's solution was used for fluid maintenance and blood products were administered when necessary. Intraoperative blood salvage and cell saver were used according to the estimation of bleeding by surgeons. Sufentanil or morphine was used via patient-controlled intravenous analgesia pump for postoperative analgesia. All patients received posterior hemivertebra resection and vertebral fusion in prone position by the same group of surgeons. A drainage tube was placed underneath paravertebral muscles before closing. After the operation, with adequate spontaneous ventilation and airway reflexes, all patients were extubated and back to postanesthesia care unit or ward.

\section{Measurements}

Demographic, surgical and anesthesia data such as age, sex, height, weight, anesthesia time and operation time were collected through electronic medical record system and there were no missing data. CBCs before and up to 7 days after surgery were also retrieved. The baseline $\mathrm{CBC}$ was taken as the latest report before surgery. If there were more than one $\mathrm{CBC}$ report within $24 \mathrm{~h}$, the average was calculated and recorded for that day. Since 
most of the reference intervals of parameters in $\mathrm{CBC}$ were similar between children aging 2 to 5 years old and adults [8], and the patients included were within this age range, the diagnostic criteria used in our hospital was thought to be appropriate in our study. Anemia was defined as hemoglobin $<110 \mathrm{~g} / \mathrm{L}$. Macrocytosis and microcytosis were defined as mean corpuscular volume $(\mathrm{MCV})<82 \mathrm{fL}$ or $>97 \mathrm{fL}$. Anisocytosis was defined as red cell distribution width (RDW) $>15 \%$. Hypochromatosis and hyperchromatosis were defined as mean corpuscular hemoglobin concentration $(\mathrm{MCHC})<320 \mathrm{~g} / \mathrm{L}$ or $>360 \mathrm{~g} / \mathrm{L}$. The concentration and maintenance time of $\mathrm{N}_{2} \mathrm{O}$ were recorded. The cumulative exposure dose was calculated as the result of multiplying the concentration by the exposure time of $\mathrm{N}_{2} \mathrm{O}$. The differences between the highest index during 7 days after surgery and the index before surgery were taken as the peak change of MCV and RDW ( $\triangle \mathrm{MCV}, \triangle \mathrm{RDW})$. And the differences divided by preoperative values were recorded as the relative changes of $\triangle \mathrm{MCV}$ and $\triangle \mathrm{RDW}(\mathrm{r} \triangle \mathrm{MCV}, \mathrm{r} \triangle \mathrm{RDW})$. Moreover, data were collected on intraoperative blood loss, fluid infusion and perioperative red blood cell transfusion. Different types of blood transfusion concluding autologous or allogeneic or mixed red cell transfusion were recorded and analyzed separately.

\section{Statistical analysis}

The sample size of this study was limited by the time the electronic medical record system was used. Patients were divided into two groups according to the record of $\mathrm{N}_{2} \mathrm{O}$ use: patients who received $\mathrm{N}_{2} \mathrm{O}$ for the maintenance of anesthesia $\left(\mathrm{N}_{2} \mathrm{O}\right.$ group), and patients who received air instead (Air group).

Demographic characteristics and perioperative data were described and analyzed firstly. The KolmogorovSmirnov test was applied to check for distribution normality. If the data was non-normally distributed, a twotailed Mann-Whitney $U$ test was used. And if the data was normally distributed a two-tailed unpaired $t$ test was used. The amount of intraoperative blood loss, fluid infusion and red cell transfusion were analyzed by the Mann-Whitney $U$ test. The fraction of different kinds of transfusion was calculated and Chi-squared test was used to determine significant differences between the two groups. The incidence of anemia, macrocytosis, microcytosis, anisocytosis, hypo- and hyperchromatosis were described and analyzed in the same way. The twotailed unpaired $t$ test was used to compare $\triangle \mathrm{MCV}$ and $\mathrm{r} \triangle \mathrm{MCV}$ and the two-tailed Mann-Whitney $U$ test was used to compare $\triangle \mathrm{RDW}$ and $\mathrm{r} \triangle \mathrm{RDW}$. To explore the association between cumulative $\mathrm{N}_{2} \mathrm{O}$ exposure and $\mathrm{r} \triangle \mathrm{MCV}$ and $\mathrm{r} \triangle \mathrm{RDW}$, Spearman correlation coefficient and $95 \%$ confidence interval $(\mathrm{CI})$ were calculated. Baseline factors thought to be associated with $\mathrm{r} \triangle \mathrm{MCV}$ were regarded as potential confounders for analysis. Based on previous studies and clinical experiences, age, sex, blood loss amount [9], intraoperative fluid infusion, allogeneic transfusion amount and exclusively allogeneic transfusion percentage $[10,11]$ were adjusted in multiple liner regression analysis. IBM SPSS version 22 was used for statistical analysis, and a 2 -tailed $P$ value of $<0.05$ was considered significant.

\section{Results}

One hundred sixty-two patients were screened and in total 136 patients were included in this retrospective cohort study, of which 65 were in the air group and 71 were in the $\mathrm{N}_{2} \mathrm{O}$ group. The flow chart was shown in Fig. 1. The demographic characteristics before surgery were shown in Table 1 . There was no significant difference between the two groups, except for the expected larger exposure dose in the $\mathrm{N}_{2} \mathrm{O}$ group.

Blood loss, fluid infusion and red cell transfusion during and after surgery were listed in Table 2 . There was no difference in intraoperative blood loss and fluid infusion between the two groups. 127(93.4\%) patients were transfused during surgery, among which $60(92.3 \%)$ were in the air group and 67(94.4\%) were in the $\mathrm{N}_{2} \mathrm{O}$ group. $20(30.8 \%)$ and $34(47.9 \%)$ patients in air group and $\mathrm{N}_{2} \mathrm{O}$ group received only allogeneic blood transfusion $(P=$ 0.042 ), and the transfusion volume was 200 [200-400] and 200[200-400] respectively $(P=0.761) .7(10.8 \%)$ and $6(8.5 \%)$ patients in air group and $\mathrm{N}_{2} \mathrm{O}$ group received only autologous blood transfusion $(P=0.646)$ and the transfusion volume was $130[128-139]$ and 123[109-174] $(P=0.445) .33(50.8 \%)$ and $27(38.0 \%)$ patients in air group and $\mathrm{N}_{2} \mathrm{O}$ group received both kinds of transfusion $(P=0.135)$, and the transfusion volume was 349[327516] and 350[325-514] $(P=0.761)$. Besides, only $2(3.1 \%)$ patients in the air group and $1(1.4 \%)$ patient in $\mathrm{N}_{2} \mathrm{O}$ group received blood transfusion after operation. Through the transfusion type were different between the two groups, there was no significant discrepancy in blood transfusion volume.

The fraction of hematologic disorders was shown in Table 3. 42(64.6\%) and 30(42.3\%) patients in the air and $\mathrm{N}_{2} \mathrm{O}$ group developed anemia $(P=0.009)$. No macrocytosis happened, but $37(56.9 \%)$ and $37(52.1 \%)$ patients had microcytosis in the air group and the $\mathrm{N}_{2} \mathrm{O}$ group $(P=$ $0.574)$. There was $1(1.5 \%)$ patient in the air group with hypochromatosis. $4(6.2 \%)$ and $3(4.2 \%)$ patients developed hyperchromatosis separately in the air group and the $\mathrm{N}_{2} \mathrm{O}$ group $(P=0.709)$. Besides $6(9.2 \%)$ and $5(7.0 \%)$ patients in the two groups developed anisocytosis. These results suggested a change in red blood cell morphology, mainly in hemoglobin and MCV. The blood loss and transfusion volume may be a contributing factor. 


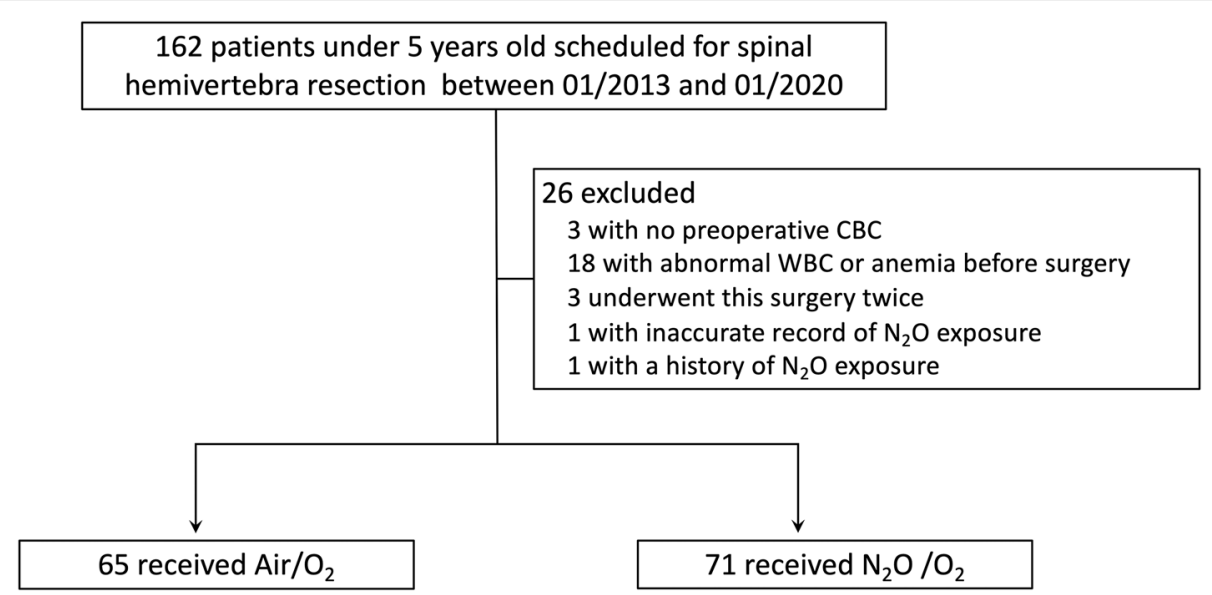

Fig. 1 Flowchart. Legend: Flow chart showing inclusion and exclusion of patients for spinal hemivertebra resection. CBC, complete blood count; WBC, white blood cell; $\mathrm{N}_{2} \mathrm{O}$, nitrous oxide

The variations of MCV, mean corpuscular hemoglobin $(\mathrm{MCH}), \mathrm{MCHC}$ and RDW before and within 3 days after surgery were shown as mean and $95 \%$ confidence interval (CI) in Fig. 2(A-D). MCV peaked at 83.7(82.9-84.4) $\mathrm{fL}$, and 83.2(82.4-83.9) fL and RDW peaked at $13.8 \%$ (13.4-14.2\%), and 13.9\% (13.6-14.2\%) for the air group and the $\mathrm{N}_{2} \mathrm{O}$ group during the week after operation. And the absolute and relative changes within 7 days after surgery were also shown in Fig. 2(E-H). Both $\mathrm{r} \triangle \mathrm{MCV}$ and $\mathrm{r} \triangle \mathrm{RDW}$ were similar between the two groups. No correlation was observed between cumulative $\mathrm{N}_{2} \mathrm{O}$ exposure and $\mathrm{r} \Delta \mathrm{MCV}(n=136 ; \mathrm{r}=-0.009 ; 95 \% \mathrm{CI},-0.196$ to $0.173 ; P=0.918)$ or $\mathrm{r} \Delta \mathrm{RDW} \quad(n=136 ; r=-0.048$; $95 \% \mathrm{CI},-0.215$ to $0.115 ; P=0.583$ ).
Variables associated with $\mathrm{r} \triangle \mathrm{MCV}$ based on existing literature and clinical experience were included for multiple liner regression analysis. After adjusted for age, sex, blood loss amount, intraoperative fluid infusion, allogenic transfusion amount and exclusively allogeneic transfusion percentage, $\mathrm{N}_{2} \mathrm{O}$ exposure was still not associated with $\mathrm{r} \triangle \mathrm{MCV}$ (Table 4).

\section{Discussion}

We conducted a comprehensive analysis of red blood cell morphology changes in pre-school age children undergoing hemivertebra resection in this retrospective study. No megaloblastic anemia or macrocytosis were

Table 1 Demographic characteristics and perioperative data

\begin{tabular}{|c|c|c|c|}
\hline & Air group & $\mathrm{N}_{2} \mathrm{O}$ group & $P$ value \\
\hline Number of patients & 65 & 71 & \\
\hline Male, N (\%) & $42(64.6)$ & $46(64.8)$ & 0.983 \\
\hline Age (months) & $43.6 \pm 14.4$ & $43.5 \pm 13.0$ & 0.827 \\
\hline Weight (kg) & $15.7 \pm 4.1$ & $16.1 \pm 3.7$ & 0.381 \\
\hline Height (cm) & $97.3 \pm 10.7$ & $97.6 \pm 10.7$ & 0.789 \\
\hline Duration of surgery (min) & $167.5 \pm 37.1$ & $172.4 \pm 35.5$ & 0.265 \\
\hline Duration of anesthesia (min) & $233.6 \pm 38.8$ & $230.9 \pm 40.0$ & 0.912 \\
\hline $\mathrm{N}_{2} \mathrm{O}$ inspiration concentration (\%) & n.a. & $50[50-50]$ & $<0.001$ \\
\hline Cumulative $\mathrm{N}_{2} \mathrm{O}$ dose $\left(\mathrm{N}_{2} \mathrm{O} \times\right.$ time $)$ & n.a. & $100.5[84.0-112.5]$ & $<0.001$ \\
\hline Length of stay (days) & $13.8 \pm 4.2$ & $13.6 \pm 4.8$ & 0.766 \\
\hline Preoperative red blood cell $\left(10^{12} / \mathrm{L}\right)$ & $4.6 \pm 0.4$ & $4.6 \pm 0.3$ & 0.828 \\
\hline Preoperative hemoglobin (g/L) & $127.7 \pm 9.1$ & $126.7 \pm 7.1$ & 0.496 \\
\hline Preoperative white blood cell $\left(10^{9} / \mathrm{L}\right)$ & $7.0 \pm 1.5$ & $7.0 \pm 1.4$ & 0.945 \\
\hline Preoperative platelet $\left(10^{9} / \mathrm{L}\right)$ & $314.3 \pm 73.3$ & $293.9 \pm 68.7$ & 0.094 \\
\hline
\end{tabular}

Data are presented as numbers (percentage), or mean \pm standard deviation. $\mathrm{N}_{2} \mathrm{O}$ nitrous oxide; $n . a$. not applicable due to low count 
Table 2 Perioperative Blood Loss, Fluid Infusion and Blood Transfusion

\begin{tabular}{|c|c|c|c|}
\hline & Air group & $\mathrm{N}_{2} \mathrm{O}$ group & $P$ value \\
\hline Intraoperative blood loss (mL) & 200 [125-300] & $200[100-300]$ & 0.722 \\
\hline Intraoperative fluid infusion (mL) & $500[400-800]$ & $540[400-750]$ & 0.948 \\
\hline No red cell transfusion, N (\%) & $5(7.7)$ & $4(5.6)$ & 0.737 \\
\hline \multicolumn{4}{|l|}{ Intraoperative red cell transfusion } \\
\hline N (\%) & $60(92.3)$ & $67(94.4)$ & 0.737 \\
\hline Volume $(\mathrm{mL})$ & 325 [200-400] & $270[200-400]$ & 0.780 \\
\hline \multicolumn{4}{|l|}{ Exclusively allogeneic transfusion } \\
\hline N (\%) & $20(30.8)$ & $34(47.9)$ & 0.042 \\
\hline Volume (mL) & $200[200-400]$ & 200 [200-400] & 0.761 \\
\hline \multicolumn{4}{|l|}{ Exclusively autologous transfusion } \\
\hline$N(\%)$ & $7(10.8)$ & $6(8.5)$ & 0.646 \\
\hline Volume $(\mathrm{mL})$ & 130 [128-139] & 123 [109-174] & 0.445 \\
\hline \multicolumn{4}{|l|}{ Mixed transfusion } \\
\hline$N(\%)$ & $33(50.8)$ & $27(38.0)$ & 0.135 \\
\hline Volume $(\mathrm{mL})$ & $349[327-516]$ & $350[325-516]$ & 0.761 \\
\hline \multicolumn{4}{|l|}{ Postoperative red cell transfusion } \\
\hline N (\%) & $2(3.1)$ & $1(1.4)$ & 0.606 \\
\hline
\end{tabular}

observed. There was no correlation between $\mathrm{N}_{2} \mathrm{O}$ exposure and $\mathrm{r} \triangle \mathrm{MCV}$ or $\mathrm{r} \triangle \mathrm{RDW}$.

Children with congenial scoliosis are at risk of malignant hyperthermia, so total intravenous anesthesia and ventilation with $\mathrm{N}_{2} \mathrm{O} / \mathrm{O}_{2}$ or air/ $\mathrm{O}_{2}$ are applied during surgery. We planned to do this cohort study on these young children for two reasons. On one hand, $\mathrm{N}_{2} \mathrm{O}$ is a wildly used inhalation anesthetic while its use remains controversial for its potential side effects related to vitamin $B_{12}$ oxidation [12]. With impaired tetrahydrofolate and methionine synthesis, deoxyribonucleic acid (DNA) synthesis and cell cycle arrest could happen [13]. Acute megaloblastic bone marrow changes were found in seriously ill patients with $\mathrm{N}_{2} \mathrm{O}$ exposure for 2 to $6 \mathrm{~h}$ [14]. Recently several studies [2-4] have found elevated plasma homocysteine concentration under $\mathrm{N}_{2} \mathrm{O}$ anesthesia. Duma explored the hematological changes in 54 adolescent patients after major spinal surgery and found no association between $\mathrm{N}_{2} \mathrm{O}$ exposure and megaloblastic anemia. However, more studies are still needed to clarify the clinical effect like blood cell morphology or neurobehavioral changes. On the other hand, given its dose-dependent side effects [15], a study on risk population with large $\mathrm{N}_{2} \mathrm{O}$ exposure will help describe its clinical safety. Pre-school age children with active DNA synthesis are vulnerable and they tend to receive large amount of $\mathrm{N}_{2} \mathrm{O}$ anesthesia because of high respiratory rate and short drug half-time. Hemivertebrae resection are applied in patients with congenital scoliosis due to hemivertebrae and usually takes around $4 \mathrm{~h}$. Current evidence has shown an exposure of $\mathrm{N}_{2} \mathrm{O}$ for only $2 \mathrm{~h}$ could increase plasma homocysteine in young children [4]. Therefore, we did this retrospective cohort study on pre-school age children undergoing hemivertebrae resection but found no significant changes in MCV and RDW after long exposure of $\mathrm{N}_{2} \mathrm{O}$.

Table 3 Incidence of Abnormality in Red Blood Cell up to Seven Days after Surgery

\begin{tabular}{llll}
\hline & Air group & $\mathbf{N}_{\mathbf{2}} \mathbf{O}$ group & $P$ value \\
\hline Anemia $(\mathrm{Hb}<110 \mathrm{~g} / \mathrm{L}), \mathrm{N}(\%)$ & $42(64.6)$ & $30(42.3)$ & 0.009 \\
Macrocytosis $(\mathrm{MCV}>97 \mathrm{fL}), \mathrm{N}(\%)$ & 0 & 0 & - \\
Microcytosis $(\mathrm{MCV}<82 \mathrm{fL}), \mathrm{N}(\%)$ & $37(56.9)$ & $37(52.1)$ & 0.574 \\
Hypochromatosis $(\mathrm{MCHC}<320 \mathrm{~g} / \mathrm{L}), \mathrm{N}(\%)$ & $1(1.5)$ & $3(0)$ & 0.478 \\
Hyperchromatosis $(\mathrm{MCHC}>360 \mathrm{~g} / \mathrm{L}), \mathrm{N}(\%)$ & $4(6.2)$ & $5(7.0)$ & 0.709 \\
Anisocytosis (RDW > 15\%), N (\%) & $6(9.2)$ & 0.640 \\
\hline
\end{tabular}

Data are presented as numbers (percentage). $\mathrm{N}_{2} \mathrm{O}$ nitrous oxide; $\mathrm{Hb}$ hemoglobin; $\mathrm{MCV}$ mean corpuscular volume; $\mathrm{MCHC}$ mean corpuscular hemoglobin concentration; $R D W$ red-cell distribution width 
Perioperative changes of red blood cell morphology

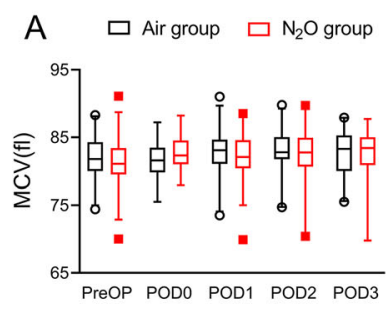

E

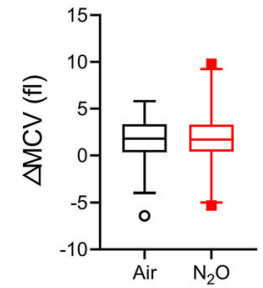

B $\square$ Air group $\square \mathrm{N}_{2} \mathrm{O}$ group

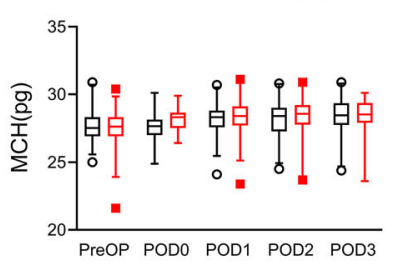

$\mathrm{F}$

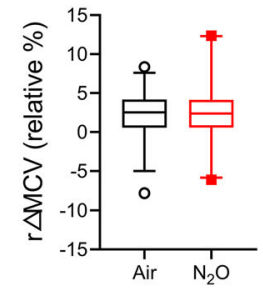

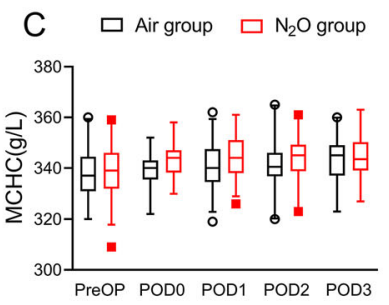

G

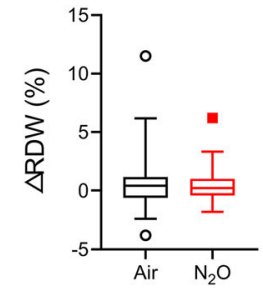

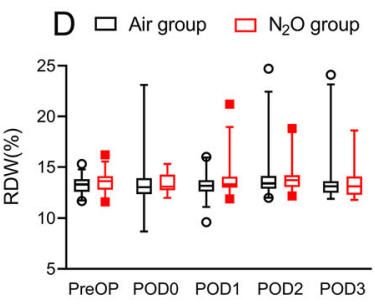

$\mathrm{H}$

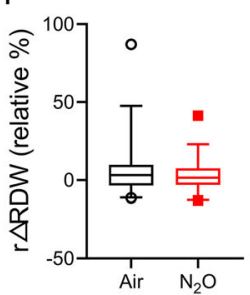

Fig. 2 Perioperative changes of red blood cell morphology. Legend: Changes in $M C V(A), M C H(B), M C H C(C)$ or RDW(D) were observed between the two groups. The absolute changes of $M C V(E)$ and $R D W(F)$ and the relative changes of $M C V(G)$ and $R D W(H)$ were shown separately. MCV, mean corpuscular volume; $\mathrm{MCH}$, mean corpuscular hemoglobin; $\mathrm{MCHC}$, mean corpuscular hemoglobin concentration; RDW, red-cell distribution width; $\triangle \mathrm{MCV}$, change of peak postoperative to preoperative mean corpuscular volume; $\triangle R D W$, change of peak postoperative to preoperative red cell distribution width; $r \Delta \mathrm{MCV}$, relative change of peak postoperative to preoperative mean corpuscular volume; $r \Delta \mathrm{RDW}$, relative change of peak postoperative to preoperative red cell distribution width; PreOP, the last blood sample before surgery; POD, blood sample of some day after surgery

A large surgery as it is, all children suffered blood loss. Indicators in $\mathrm{CBC}$ such as hemoglobin, $\mathrm{MCV}$ and RDW are used to analyze hematological changes [16]. Hemoglobin reflects the severity of anemia, meanwhile MCV and RDW are two sensitive and specific indexes to identify the type of anemia [17]. Hemorrhagic and megaloblastic anemia are two possible conditions in our study. Hemorrhagic anemia might manifest as normocytic or microcytic anemia. $\mathrm{N}_{2} \mathrm{O}$ inactivates vitamin $\mathrm{B}_{12}$ and impairs its ability to act as a methionine synthase cofactor [18], which could lead to macrocytic changes. Meanwhile, blood loss stimulates medullary hematopoiesis, making it more vulnerable

Table 4 Multiple Linear Regression Analysis for $r \Delta M C V$

\begin{tabular}{llll}
\hline Variable & B & $\mathbf{9 5 \% C l}$ & $\boldsymbol{P}$ value \\
\hline Group & $3.77 \mathrm{E}-4$ & $-0.011-0.011$ & 0.946 \\
Age $(\mathrm{y})$ & -0.006 & $-0.011--0.001$ & 0.020 \\
Sex & 0.007 & $-0.004-0.019$ & 0.206 \\
Blood loss amount (/100 $\mathrm{mL})$ & 0.005 & $8.2 \mathrm{E}-5-0.010$ & 0.054 \\
Intraoperative fluid infusion(/100 mL) & 0.001 & $-0.001-0.004$ & 0.332 \\
Allogeneic transfusion amount $(\mathrm{U})$ & -0.004 & $-0.014-0.005$ & 0.386 \\
Exclusively allogeneic transfusion $(\%)$ & 0.011 & $-0.002-0.025$ & 0.106 \\
\hline
\end{tabular}

Group is taken to represent children with or without nitrous oxide exposure. $r \triangle M C V$ relative changes of mean corpuscular volume to abnormal DNA synthesis. We analyzed the peak MCV value during the 7 days after surgery and found none developed macrocytosis. However, macrocytosis might be obscured by coexisting microcytic anemia. In this situation there would be both small and large red blood cells and an increased RDW value, showing the discrete trend of red blood cell size. We analyzed RDW to show the distribution and heterogeneity of red blood cell and found no significant difference.

Blood loss and transfusion as well as fluid management may interfere hematologic changes [19], especially during large surgeries in young children [20]. Intraoperative bleeding is one of the direct causes of postoperative anemia. Although the amount of blood transfusion was greater than intraoperative blood loss in our study, there was still a high proportion of anemia after surgery. The exact volume of bleeding should be recorded by the weighed gauze and suction bottle or calculated by hemoglobin or hematocrit changes. In our study, bleeding volume was roughly recorded and actual volume was probably underestimated. Autologous or allogeneic blood transfusion might help relieve anemia while postoperative red blood cell morphology could be interfered via allogenic transfusion $[10,11]$. The morphology changes of red blood cell are associated with the storge time and pre-school age children usually receive fresh red blood cell distributed by hospital blood bank. 
Besides, fluid management could affect hemoglobin concentrations and actual red cell loss in surgery via blood dilution or concentration. The background infusion of Ringers Lactate was set according to actual requirements during surgery and colloid or plasma could be used when necessary [21]. In this retrospective study, it was difficult to collect the exact blood loss and fluid infusion. Blood loss, the type and amount of blood transfusion and intraoperative fluid infusion were analyzed and no significant difference was found between the two groups. We included intraoperative fluid infusion amount, allogenic transfusion amount and exclusively allogenic transfusion percentage as potential confounders. After adjusting for these factors, $\mathrm{N}_{2} \mathrm{O}$ exposure was not associated with $\mathrm{r} \triangle \mathrm{MCV}$. The medium bleeding volume of $200 \mathrm{~mL}$ was about $15 \%$ of whole blood volume and was one of the key reasons for postoperative anemia.

Although no changes in red blood cell morphology were found, there are some limitations in our study. First, we only analyzed the morphologic changes of red blood cell for 7 days after surgery. Methionine synthase could be irreversibly damaged by $\mathrm{N}_{2} \mathrm{O}$ and would be de novo synthesized to recover its activity after at least 2 to 4 days depending on the protein synthesis level [22, 23]. With the damaged function of methionine synthase, abnormal DNA synthesis and hematopoieisis could happen. It takes around $188 \mathrm{~h}$ for proerythroblast to develop into mature erythrocyte, which can be accelerated by anemia and in young children. Duma et al. observed the hematologic effects of $\mathrm{N}_{2} \mathrm{O}$ for 4 days after operation and found no macrocytosis in adolescent patients [6]. In our study, many children were discharged about 4 days after surgery. We only have complete blood count results of about $1 / 3$ children for about 1 week after surgery and found no macrocytosis. The incidence of macrocytosis could be underestimated and long-term prognosis such as infection, thrombosis, changes in the nervous and cardiovascular systems due to the elevated homocysteine need further explorations. Second, we were unable to obtain iron status, vitamin $B_{12}$, folic acid and plasma homocysteine concentration, and MTHFR polymorphism in this retrospective study. $\mathrm{N}_{2} \mathrm{O}$ could cause more severe outcomes in patients with MTHFR C677T or A1298C gene variant [24]. We could better describe the effect of $\mathrm{N}_{2} \mathrm{O}$ with those above. Third, the accurate bleeding volume was unable to obtain and blood loss was probably underestimated. A $15 \%$ loss of whole blood volume in such young children was one of the main reasons of postoperative anemia and this might obscure the side effect of $\mathrm{N}_{2} \mathrm{O}$ exposure. A prospective randomized controlled trial or cohort study with accurate recording of blood loss and fluid infusion amount and pre- and post-operative iron, vitamin $\mathrm{B}_{12}$, folic acid and homocysteine concentration might help to better clarify the effect of $\mathrm{N}_{2} \mathrm{O}$ anesthesia on red blood cell morphology changes and long-term prognosis such as neurobehavioral and cardiovascular changes.

\section{Conclusions}

In conclusion, our results suggest that pre-school age children undergoing hemivertebra resection could receive $\mathrm{N}_{2} \mathrm{O}$ anesthesia for $4 \mathrm{~h}$ with a low probability of megaloblastic anemia or other changes in red blood cell morphology. More studies should be done to clarify the long-term outcomes under $\mathrm{N}_{2} \mathrm{O}$ anesthesia in pediatric patients.

\section{Abbreviations}

$\mathrm{N}_{2} \mathrm{O}$ : Nitrous oxide; DNA: Deoxyribonucleic acid; CBC: Complete blood count; MCV: Mean corpuscular volume; RDW: Red cell distribution width; $r \triangle M C V$ : Relative changes of $M C V$; r $\triangle R D W$ : Relative changes of RDW MCHC: Mean corpuscular hemoglobin concentration; Cl: Confidence interval; MCH: Mean corpuscular hemoglobin

\section{Acknowledgements}

The authors thank Yuelun Zhang (Medical Research Center, Peking Union Medical College Hospital, Beijing, China) and Xiaohan Xu (Department of Anesthesiology, Peking Union Medical College Hospital, Beijing, China) for professional advice on statistics.

\section{Authors' contributions}

RXW contributed to collect and analyze the data, and write the manuscript. LL helped to design the study and collect the data. LX helped analyze the data and revise the manuscript. BZ contributed in study design and revising the manuscript. YGH helped revise the manuscript. All authors have read and approved the final manuscript.

\section{Funding \\ None.}

Availability of data and materials

All main data were presented within the manuscript and the datasets used an analyzed during the current study are available from the corresponding author on reasonable request.

\section{Declarations}

Ethics approval and consent to participate

This study was conducted in accordance with the Declaration of Helsinki. Before data collection, the study was approved by the Medical Ethics Committee of Peking Union Medical College Hospital and the registration number was S-K1301. A waiver of consent was approved by the institutional review board of Medical Ethics Committee of Peking Union Medical College Hospital because it was a retrospective analysis.

Consent for publication

Not applicable.

\section{Competing interests}

The authors state no competing interests.

Received: 10 March 2021 Accepted: 12 May 2021

Published online: 16 June 2021

\section{References}

1. American Academy of P, American Academy of Pediatric D, Cote CJ, Wilson S, Work Group on S. Guidelines for monitoring and management of pediatric patients during and after sedation for diagnostic and therapeutic procedures: an update. Pediatrics. 2006;118(6):2587-602. https://doi.org/10.1 542/peds.2006-2780

2. Myles PS, Chan MT, Kaye DM, Mcllroy DR, Lau CW, Symons JA, et al. Effect of nitrous oxide anesthesia on plasma homocysteine and endothelial 
function. Anesthesiology. 2008;109(4):657-63. https://doi.org/10.1097/ALN. 0b013e31818629db.

3. Nagele P, Tallchief D, Blood J, Sharma A, Kharasch ED. Nitrous oxide anesthesia and plasma homocysteine in adolescents. Anesth Analg. 2011; 113(4):843-8. https://doi.org/10.1213/ANE.0b013e31822402f5.

4. Pichardo D, Luginbuehl IA, Shakur Y, Wales PW, El-Sohemy A, O'Connor DL. Effect of nitrous oxide exposure during surgery on the homocysteine concentrations of children. Anesthesiology. 2012;117(1):15-21. https://doi. org/10.1097/ALN.0b013e318259a8cc.

5. Sanders RD, Weimann J, Maze M. Biologic effects of nitrous oxide: a mechanistic and toxicologic review. Anesthesiology. 2008;109(4):707-22. https://doi.org/10.1097/ALN.0b013e3181870a17.

6. Duma A, Cartmill C, Blood J, Sharma A, Kharasch ED, Nagele P. The hematological effects of nitrous oxide anesthesia in pediatric patients. Anesth Analg. 2015;120(6):1325-30. https://doi.org/10.1213/ANE. 0000000000000642.

7. Wang S, Zhang J, Qiu G, Li S, Zhang Y, Yang Y, et al. Posterior-only Hemivertebra resection with anterior structural reconstruction with titanium mesh cage and short segmental fusion for the treatment of congenital Scoliokyphosis: the indications and preliminary results. Spine (Phila Pa 1976). 2017:42(22):1687-92. https://doi.org/10.1097/BRS.0000000000002197.

8. Li J, Zhang H, Huang X, Zhang J, Wu X. Establishment of reference intervals for complete blood count parameters in venous blood for children in the Xiamen area, China. Int J Lab Hematol. 2019;41(5):691-6. https://doi.org/1 0.1111/ijlh.13095.

9. Janus J, Moerschel SK. Evaluation of anemia in children. Am Fam Physician. 2010;81(12):1462-71.

10. Ichikawa J, Koshino I, Komori M. Dose-dependent effect of stored-blood transfusions on recipient red blood cell indices, deformability and density. Vox Sang. 2019;114(2):174-7. https://doi.org/10.1111/vox.12742.

11. Salaria ON, Barodka VM, Hogue CW, Berkowitz DE, Ness PM, Wasey JO, et al. Impaired red blood cell deformability after transfusion of stored allogeneic blood but not autologous salvaged blood in cardiac surgery patients. Anesth Analg. 2014;118(6):1179-87. https://doi.org/10.1213/ANE. 0000000000000227.

12. Annequin D. Nitrous oxide (N2O) angel or devil? Paediatr Anaesth. 2020 30(4):388-9. https://doi.org/10.1111/pan.13834.

13. Green R. Vitamin B12 deficiency from the perspective of a practicing hematologist. Blood. 2017;129(19):2603-11. https://doi.org/10.1182/blood-2 016-10-569186.

14. Amos RJ, Amess JA, Hinds CJ, Mollin DL. Incidence and pathogenesis of acute megaloblastic bone-marrow change in patients receiving intensive care. Lancet. 1982;2(8303):835-8. https://doi.org/10.1016/s0140-6736(82 ) $90808-\mathrm{x}$.

15. Krajewski W, Kucharska M, Pilacik B, Fobker M, Stetkiewicz J, Nofer JR, et al. Impaired vitamin B12 metabolic status in healthcare workers occupationally exposed to nitrous oxide. Br J Anaesth. 2007;99(6):812-8. https://doi.org/10.1 093/bja/aem280

16. Buttarello M. Laboratory diagnosis of anemia: are the old and new red cell parameters useful in classification and treatment, how? Int I Lab Hematol. 2016;38(Suppl 1):123-32. https://doi.org/10.1111/ij|h.12500.

17. Brugnara C, Mohandas N. Red cell indices in classification and treatment of anemias: from M.M. Wintrobes's original 1934 classification to the third millennium. Curr Opin Hematol. 2013;20(3):222-30. https://doi.org/10.1097/ MOH.0b013e32835f5933.

18. van Amsterdam J, Nabben T, van den Brink W. Recreational nitrous oxide use: prevalence and risks. Regul Toxicol Pharmacol. 2015;73(3):790-6. https:// doi.org/10.1016/j.yrtph.2015.10.017.

19. Ohrt-Nissen S, Bukhari N, Dragsted C, Gehrchen M, Johansson PI, Dirks J, et al. Blood transfusion in the surgical treatment of adolescent idiopathic scoliosis-a single-center experience of patient blood management in 210 cases. Transfusion. 2017;57(7):1808-17. https://doi.org/10.1111/trf.14137.

20. Ma C, Lumb R, Walker EV, Foshaug RR, Dang TT, Verma S, et al. Noninvasive fecal immunochemical testing and fecal Calprotectin predict mucosal healing in inflammatory bowel disease: a prospective cohort study. Inflamm Bowel Dis. 2017;23(9):1643-9. https:/doi.org/10.1097/MIB.0000000000001173.

21. Sumpelmann R, Becke K, Zander R, Witt L. Perioperative fluid management in children: can we sum it all up now? Curr Opin Anaesthesiol. 2019;32(3): 384-91. https://doi.org/10.1097/ACO.0000000000000727.

22. Culley DJ, Raghavan SV, Waly M, Baxter MG, Yukhananov R, Deth RC, et al. Nitrous oxide decreases cortical methionine synthase transiently but produces lasting memory impairment in aged rats. Anesth Analg. 2007; 105(1):83-8. https://doi.org/10.1213/01.ane.0000266491.53318.20.

23. Riedel B, Fiskerstrand T, Refsum H, Ueland PM. Co-ordinate variations in methylmalonyl-CoA mutase and methionine synthase, and the cobalamin cofactors in human glioma cells during nitrous oxide exposure and the subsequent recovery phase. Biochem J. 1999;341(Pt 1):133-8. https://doi. org/10.1042/bj3410133.

24. Nagele P, Zeugswetter B, Wiener C, Burger H, Hupfl M, Mittlbock M, et al. Influence of methylenetetrahydrofolate reductase gene polymorphisms on homocysteine concentrations after nitrous oxide anesthesia. Anesthesiology. 2008;109(1):36-43. https://doi.org/10.1097/ALN.0b013e318178820b.

\section{Publisher's Note}

Springer Nature remains neutral with regard to jurisdictional claims in published maps and institutional affiliations.

\section{Ready to submit your research? Choose BMC and benefit from:}

- fast, convenient online submission

- thorough peer review by experienced researchers in your field

- rapid publication on acceptance

- support for research data, including large and complex data types

- gold Open Access which fosters wider collaboration and increased citations

- maximum visibility for your research: over $100 \mathrm{M}$ website views per year

At BMC, research is always in progress.

Learn more biomedcentral.com/submissions 